\title{
Facets of Democracy: An Overview
}

\author{
Aswasthama Bhakta Kharel, $\mathrm{PhD}^{*}$
}

\begin{abstract}
Democracy allows the expression of political preferences of citizens in a state. It advocates the rule of law, constraints on executive's power, and guarantees the provision of civil liberties. It also manages to ensure human rights and fundamental freedoms of people. In democracy, people are supposed to exercise their freely expressed will. Ordinary people hold the political power of the state and rule directly or through elected representatives inside a democratic form of government. Democracy is a participatory and liberal way of governing a country. Different countries in the world have been practicing various models of democracy. There remains the participation of people in government and policy-making of the state under democracy. But when the majority can pull the strings of the society without there being legislation for protecting the rights of the minority, it may create a severe risk of oppression. Many countries of the world at the present time are facing democratic deficits. In several countries, the democratic practices are not adequately regulated and governed, as a result, the rise of violations of rules of law is observed. Even a few countries practicing democracy are not living peacefully. This situation has put a significant question about the need and sustainability of democracy. Democracy is a widely used system of governance beyond having several challenges. Here the concept, origin, models, dimensions, practices, challenges, solutions, and future of democracy are dealt to understand the structure of ideal democracy.
\end{abstract}

Keywords: democracy, human rights, rule of law, sustainable development, election

\section{Methodology}

The methodology applied in maintaining this research paper includes documentary analysis qualitatively where different journals, public documents, organizational reports, articles, and books are referred, and their factual data are considered. For the brief analysis and description of different terminologies that have

${ }^{*}$ Dr. Kharel holds Ph.D. in Human Rights from Tribhuvan University. He had worked at National Human Rights Commission, Nepal as an investigation officer. His interest areas are Human Rights, Democracy, Local and International Organizations, Comparative Governance and Political Systems. Currently, he is a lecturer at the Central Department of Political Science, Tribhuvan University, Nepal. 
been used in this research paper, the discussions made by recognized authors in their international journals and books are cited. Similarly, several data are extracted from published historical reports as well. By the analysis of all those collected data sources and the opinions put forward by social scientists and analysts, this research paper has tried to sketch the way forward of the democratic practice in the world in the time to come.

\section{Concept}

Democracy is the word derived from Greek dēmokratiā, coined from 'dēmos' and 'Kratos' in the $5^{\text {th }}$ century BC (Before Christ) for denoting the political system existing in some Greek city-state, notably Athens. 'dēmos' meaning people, and 'Kratos' meaning rule (MOAD, 2018), therefore 'Democracy' is a system of government in which power is vested in the people (Dahl, 2012). Democracy is a competitive political system in which competing leaders and organizations define the public policy alternatives in such a way that the public can participate in the decisionmaking process (Schattschneider, 1960). Democracy is the diffusion of power, representation of interests, and recognition of minorities (Calhoun, 2018). It is the government of the people, by the people, for the people (Lincoln, 1863). In a democratic form of government in Athens, the institutions were continually evolving to ensure, intending to ensure that the 'demos' (people) were not dominated by the wealthy oligarchs. They had abused their power for centuries. Democracy practices the government by the people where the supreme power is vested in the people and exercised directly by them or their elected agents under a free electoral system. Democracy is indeed a set of ideas and principles about freedom. Democracy is the institutionalization of freedom (Salsburg, 2005).

Democracy provides the general public with a chance to become personally involved with their government. It encourages equality among people in a positive way. It reduces issues with exploitation and is also a comparatively consistent form of government structure. Democracy provides a significantly less chance of people entering into armed conflicts and encourages centrism more than extremism. Democracy is the worst form of government except for all those who have been tired (Winston Churchill, 1947). The structure of democracy is dependent only upon the will of the majority, whereas democratic form requires more time for implementing changes. The conflict of interests within the government may occur in democracy. If power moves away from the people to only a privileged few under the democracy, it will only be a few steps away from a dictatorship. Therefore, democracy, when performed and regulated with proper concern and consent, becomes a fruitful system for the overall development of the country and prosperity. 
The GSoD conceptual framework and its link to the Sustainable Development Goals
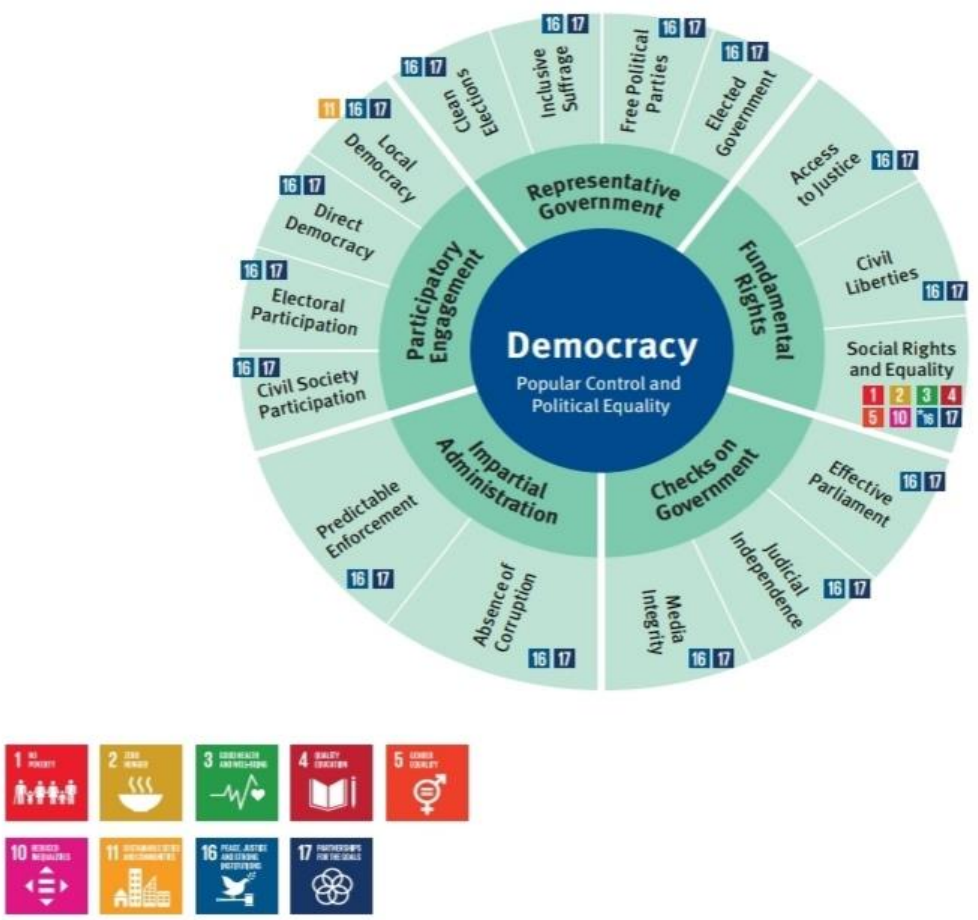

Fig (1)- Chart representing the fundamental determinants of a Democratic system

\section{History of Democracy}

Democracy began from the Greek city-state during the $6^{\text {th }}$ Century, BC 508-507 BCE (Oliver, 1993) by Cleisthenes, followed by its re-emergence and rose from the $17^{\text {th }}$ Century; to the present day. The Greek government system was closer to a real democracy as civilization was broken down into small city-states, and democratic practices were performed. Greek democratic institutions collapsed under the imperial onslaught of Macedonia and later of Rome (Riker, 2017). It is believed that Sumerian city-states have had some form of democratic setup initially. The Roman Empire (50927 BCE) practiced representative democracy with the representatives from the Senate's nobility and representatives from the commoners in the Assembly; Cicero and other political philosophers explained that governmental and political power should come from the people. In the middle ages, the people's rights were advertised, and such requests were defended by the development of the courts' system. It introduced the ideas of king councils, assemblies, and eventually, parliamentary systems. Iceland had a parliament as early as $930 \mathrm{AD}$ (Civatitis, 2018). Lots of democratic developments have been seen afterward, some of which were the Magna Carta of 1215 (British Library, 
2015) followed by Petition of Right in 1628 (House of Commons, 1628) and Bill of Rights in 1689 (Yale Law School, 2008). Renaissance brought a new wave of modern democracy during the $16^{\text {th }}$ Century.

The French Revolution in France gave the rights and powers back to the French people. The Reform Act of $7^{\text {th }}$ June 1832 established the parliamentary reforms in Britain (UK; Parliament, 1832). In the $19^{\text {th }}$ Century, many more countries became democracies, and the right to vote was expanded to almost all groups of people of those democratic nations. The two world wars, World War I, 1914-1918 (Library of Congress, 1919) and World War II, 1939-1945 (Chambers, 2000) of the $20^{\text {th }}$ Century; brought chaos, took lives of millions of people, caused massive poverty and resulted in widespread of epidemic diseases along with the destruction of world humanity. It is questioned the significance and usefulness of democracy. Later on, education was felt essential as a weapon to safeguard democracy, so an emphasis on global education, was forwarded. Today we can observe both the praises and criticisms for democracy in different parts of the world and the discussions of various alternatives to democracy.

\section{Models of Democracy}

Different forms of democracy were and are being practiced in different parts of the world, some of which are discussed below:

\section{Classical Democracy}

Classical democracy refers to a direct democracy developed in ancient times in the Greek city-state of Athens. The mass meetings, lottery, and elections were used to be conducted under classical Democracy. The scope of participation was maintained in the office of the state. Thucydides (460-399 BC) claimed that Athenian Democracy was unique because its constitution, administrative system, and institution were not copied from any other method (Manutius, 1502). Classical Democracy was also called the tyranny of the minority. The treatment out of the slaves and immigrants did not prove the existence of rights and equality in Athenian society.

\section{Protective Democracy}

The central theme of Classical Democracy was the participation of all the citizens in the process of state and the Athenian, whereas the protective democracy highlights an entirely different aspect. It is simply known as a liberal democracy, which is a representative democracy with protection for individual freedom and property by the rule of law. It believes in popular sovereignty, but since people stop taking part in the state's process, they do it through their representatives. The importance of protecting the rights, liberties, and distribution of privileges is the division of powers among legislature, executive, and judiciary. This is all done in liberal democracies. There are also some measures to prevent the violation of rights and liberties. 
Competition in all spheres is the feature of protective democracy. If the state administration and structures are re-arranged and re-modeled; adequately and successfully, it is believed that democracy will ultimately become defensive in practice. To draw a clear line between state and civil society is a critical aspect of defensive Democracy. The protagonists of defensive Democracy stressed all the boundaries of civil society, cultural and economic organization.

\section{Developmental Democracy}

If the liberty or the life of an individual is in danger, the state intervention is justified. So far as the action of the individual is concerned, their interests, or issues, they are allowed to enjoy absolute liberty. In a developmental democracy, the involvement of citizens is found, and the voting mechanism is held regularly. Representable Democracy and popular sovereignty has observed in Developmental democracy.

\section{Participatory Democracy}

Participatory democracy or Participative democracy emphasizes the board participation of constituent in the direction and operation of the political system. In other words, participatory Democracy is a form of government in which the cities have the opportunity to decide on public policy. Participatory Democracy is not a noble concept and has existed under various political designs since the Athenian Democracy. The theory of participatory Democracy developed by Jean-Jacques Rousseau and later by J.S. Mill and G.D.H. Cole. The most crucial aim of participatory democracy is to make people interested in the political, legal and economical process of the state. Direct involvement will be able to enlighten participatory democracy. It is another purpose to kindle up the innovative qualities of man. Direct participation in the function and decision-making process is one of the executive's powers, features of participatory democracy. A system that has adopted a participatory democratic approach-modeled; and re-molds the social and political structure so that democracy can function smoothly. Rights and liberties are also emphasized by participatory democracy.

\section{Cosmopolitan Democracy}

Cosmopolitan Democracy is the political theory that explores the application of norms and values of democracy at the transnational and the global sphere. It argues about the global governance of the people (Rosenberg, 2011). A cosmopolitan democracy would seek to entrench and develop democratic institutions at the regional and international levels. The Cosmopolitan model of democracy is a compromise between the importance, significance and requirements of nation-states on the one hand and the globalization or cosmopolitisation of politics, economy, and culture on the others. It has suggested that the global parliament should be set up to deal with global 
issues and a military body to settle military matters. For the purpose of tackling the legal issues, a judicial body should be set up or present the International Court of Justice (ICJ, 2018) armed with more powers.

\section{Dimensions of Democracy}

Democracy is based on two competing visions of democratic ideals, such as majoritarian principles and consensus principles. They are describing the dimensions of democracy. It distinguished into majoritarian, consensus, and direct democracy. In majoritarian democracy, the government ruled by most people for which mass participation of people required. Here citizens can control the government as long as they have enough mechanisms for participation. Referenda, initiatives, and recalls were used to decide government policies. In consensus democracy, the inclusive government is made by the involvement of as many people as favorable with a majority of support from society merely being a minimal threshold. In a direct democracy, people decide on policy initiatives directly. The three significant dimensions of democracy are power, participation, and wisdom (Co-Intelligence Institute, 2018). In democracy, power is in the hands of general people with their involvement in the political affairs of the country, where people choose their representatives to rule the nation using their wisdom and rationality.

Broadly dimensions of democracy were observed as social democracy, economic democracy, and Political democracy. Social democracy has a democratic government that serves to promote the welfare of the people. Mass media is seen to be free of governmental controls in Social democracy. The government under social Democracy also actively takes action for poverty reduction and the promotion of equality among all genders. Social Democracy thus is expected to be an evolutionary form of democratic socialism that aims to achieve socialism through an established political process rather than a social revolution. Social democracy has its core value of freedom, equality, and fraternity and the fulfillment of fundamental rights. An economic democratic ecosystem can exist within capitalist or socialist societies. Economic Democracy proposes shifting decision-making power from corporate stakeholders to a larger group of public stakeholders, including workers, suppliers, and the broader public. Therefore, who contributes to the production is entitled to have his/her share of wage and allowances in economic democracy. In a political democracy, there is equal sharing of political power by the nation's citizens, where citizens gain the ability to legislate, which they perform by delegating the legislative function to their elected representatives. Political democracy is supposed to work more smoothly and systematically in the presence of social democracy. Besides, procedural and substantive democracy studied under the dimensions of democracy. Procedural democracy emphasizes the procedures and 
institutions of democracy, where democracy is observed to have free and fair elections, political equality, and fair competition among political parties, legislative assemblies, and constitutional governments. Participation and competition saw as criteria for procedural democracy, which produces an electorally-legitimated government. Substantive democracy is comprised of representation of people. Political affairs were carried out by the general people in a substantive democracy. It is also known as a functional democracy.

\section{Practices of Democracy in the World}

Democracy has undergone a remarkable global expansion over the past four decades all over the world. It includes the development of suffrage, and strengthening of electoral process, institutions and actors central to a healthy democracy. Democracy continues to spread to countries that never experienced democracy before. Since 2008, eleven states transitioned to democracy for the first time in their history, out of which Burkina Faso and Myanmar in 2015 and Armenia and Malaysia in 2018 got transitioned to democracy.

End of World War I led to the birth of many democracies (Roser, 2019). The majority of the World's Democracies concentrated in North America and North and West Europe during 1975. North America in 2019/020 contains 100 percent of democratic countries, and Europe includes 93 percent of them, followed by Latin America ( 86 percent of the states). Europe consist of the largest share of the world's democracy (39 countries), followed by Africa (20 countries), and Latin America and the Caribbean (19 countries). The total number of democracies is equal to the combined total of hybrid regimes and non-democracies in Asia. In contrast, in Africa and the Middle East, democracies constitute less than half of total countries only (International IDEA, 2019).

Democracy has risen in quantity but is lagging in quality. The frequent failures of both new and established democracies to deliver on their promises have undermined the commitment to democratic practices in the present situation. Democratic deficits like the decline in many traditional forms of civic engagement, reduced participation in the formal institutions of democracy, and declining trust in all institutions, especially institutions of government, observed. These deficits are being exacerbated by deeply rooted economic inequality and increasing polarization socially, economically, and politically.

The process of globalization has also produced democratic deficits in global governance. The share of democracies with weak democratic performance has increased in the last decade from 20 percentages in 2008 to 25 percent in 2019 (International 
IDEA, 2019). The increase in the share of countries with the democratic deficit saw with democratic aspects such as Fundamental Rights, Social Group Equality, Civil Society Participation and Electoral Participation. Democratic backsliding, a form of democratic erosion involving the gradual and intentional weakening of checks and balance and civil liberties, has become more frequent in the last decade globally.

Number and percentage of regime types per region, 2018

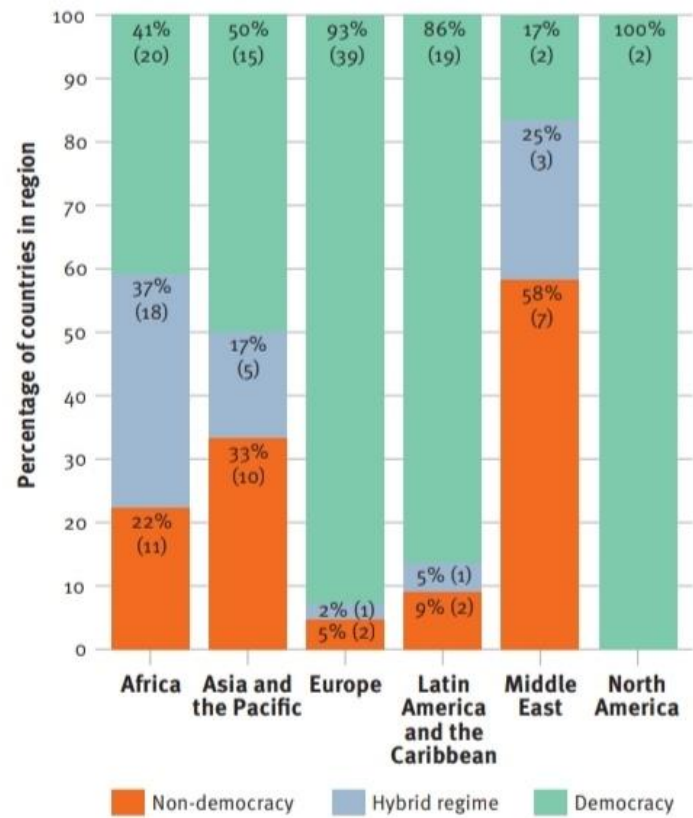

Source: International IDEA, The Global State of Democracy Indices (2019), chttp://www.idea, int/gsod-indices),
Advances in democratic aspects by region, 20132018

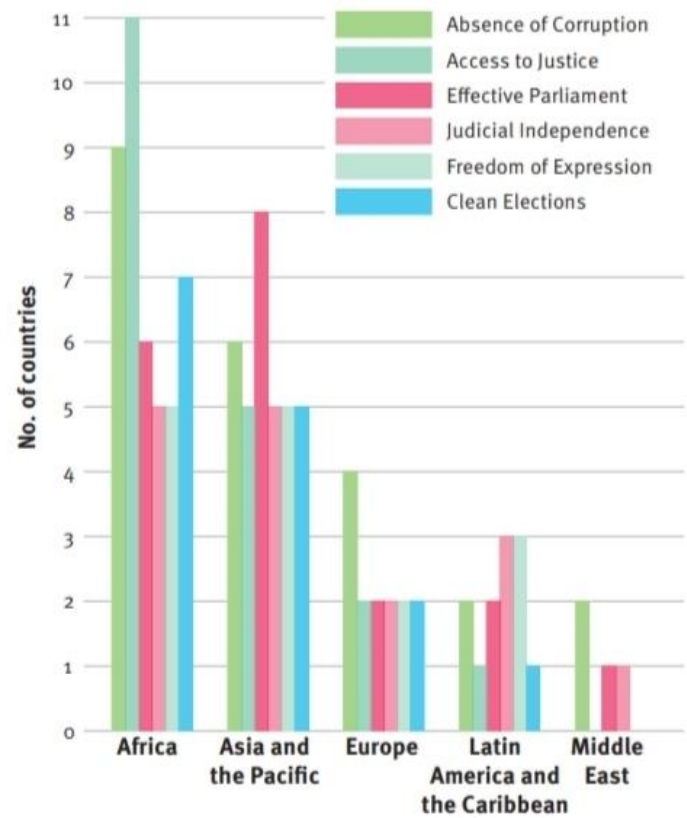

Source: International IDEA, The Global State of Democracy Indices (2019), chttp://www.idea. int/gsod-indicess.

Fig (2) - Graph indicating democratic ratios of countries in different continents (left) and a graph representing democratic advancement that has happened in the continents from 2013 to 2018 (right).

\section{Courses of Democracy in Nepal}

Nepal is a newly declared federal democratic republic nation of the $21^{\text {st }}$ Century; in the world. Democratic movements were started back in the 1940s as the campaign against the autocratic family regime of the Ranas was launched by the people and civil society. This invention of democratic activities in Nepal initiated by the Praja Parishad Party (1937) and the Nagaarik Adhikar Samitee. Shukraraj Shastri, Dharmabhakta Mathema, Dashrath Chand, and Gangalal Shrestha were sentenced to death in 1941 in the accusation of 'Parcha Kanda' against Ranas. The death sentences to these four heroic leaders of Nepal accelerated the protest against the autocratic and oppressive rule 
of Ranas in the nation. Labors in Biratnagar Jute Mill revolted against Rana in 1947 through a strike campaign. The Democratic revolution in 1951 established the democracy by the declaration of King Tribhuvan with the drafting of a new constitution through a constituent Assembly, Democracy found the freedom of practice of civil and political rights by the people.

King Mahendra, the immediate successor of King Tribhuvan, dissolved the parliament formed through the first general election in 1959 and abandoned the political parties taking all the power into his hands in 1961, using article 55 of 'Constitution for Kingdom of Nepal 1959'. Then the Partyless Panchayat system got imposed in the nation. Political parties again started revolting against the Partyless Panchayat System in various ways. Thus, the Panchayat government compelled to hold a referendum in 1980. Still, the result favored the Reformed Panchayat System (55 percentage of the total votes) over Multiparty Democracy (45 percentage of the total votes). Democratic thrusts of people could not get addressed by reformed Panchayat system because of which through the collective efforts of political parties and the general public, Mass Movement I launched in the country that abolished the Panchayat system and established Multiparty Democracy with a constitutional Monarchy in 1990. Restoration of Democracy:

The Maoist party started an armed insurgency in 1996 in Nepal. The Royal massacre took place in 2002 that left no one alive from King Birendra's family by which younger brother Gyanendra became the new King of Nepal. King Gyanendra overthrew the government led by Prime Minister Sher Bahadur Deuba and took all the executive powers into his hands. Many governments were formed and dissolved under the King, which could not meet the objectives of the king, and people because of which the King started his direct rule in 2005. But general people were not satisfied with this move of the King. Then Mass Movement II got created in April 2006, organized jointly by seven political parties and revolutionary Maoists to restore the parliament and electing of the Constituent Assembly. Thus king Gyanendra was compelled to restore the parliament. The first-ever election of the Constituent Assembly in the history of Nepal held in 2008 and in 2009, Nepal has formally declared a federal republic with the complete abolishment of Monarchy. The dissolution of the first Constituent Assembly resulted in the election of the Second Constituent Assembly in 2013 with the promulgation of a new constitution in 2015, thus smoothing the democratic movements and practices in Nepal. Some of the democratic ways in Nepal as per the 'Constitution of Nepal 2015' are secularism, federalism, sovereignty and state authority vested in the general public, independent and fair judiciary, administrative rights on Council of 
Ministers, full press freedom, citizenship by descent to a child of a Nepali father or mother and so on.

\section{Public Participation in Government and Policy Decision Making}

Public participation is how public concerns, needs, and values are incorporated into governmental and corporate decision making. It is taken as two-way communication and interaction with the overall goal of better decision-making that is supported by the public. All decisions in a Democracy should involve public participation. People participate through voting, expressing opinions on general issues and governmental actions, forming interest groups or holding public demonstrations to influence government decisions, lobbying, filing lawsuits to contest government actions, physically interfering with the execution of objectionable policy decisions, acting in partnership with government agencies, and even producing films, songs and artistic events to mobilize public attention to issues. Public participation also focused on providing input to ongoing decisions about implementation.

It is difficult to envision anything but positive outcomes from people joining the policy process, collaborating bringing positive social, environmental, and economic changes. An increase in community participation in government decisions can produce essential benefits and effective outcomes. In order to make the participatory process, it is crucial to know the technique which requires a representative cross-section of people. Time may be necessary to allow participants to develop a shared understanding of the context for the specific participatory process. Participatory methods have evolved from a variety of fields, including various academic disciplines, conflict resolution and international development. Decision making includes rational and irrational decision making where sound decision consists of the identification of problem or opportunity, brainstorming the alternating solution, and so on. In contrast, the irrational decision making comprises responding to the need for judgment and emotions. When public participation is implemented then there should be mutual trust between government and people.

\section{Challenges of Democracy}

Democracy from the very beginning of its establishment has faced numerous challenges, some of which are resolved, whereas few are yet to be determined. Challenge is that difficulty, which carries an opportunity for progress. Democratic challenges are categorized into foundational challenges, challenges of expansion of Democracy and the challenges to deepen the Democracy. Foundational challenges include the challenges to a democratic setup for the transition to Democracy like the 
establishment of the sovereign state, the formation of the constitution. Expansion challenges cover the challenge regarding the distribution of power to local people, including women, and minority groups as representatives for the development and maintenance of democratic control. Deepening challenges of democracy comprise challenges for strengthening political institutions and practices of democracy and the care of equality amongst all people to deepen the roots of Democracy.

Democratic challenges can be of different kinds that a country may face, such as challenges regarding constitution's design, democratic rights, working of public and private institutions, elections, decentralization and accommodation of diversity, political organization, and many more. Democracy has faced challenges to overcome extreme polarization resulting in democratic decay. Intense partisan polarization has created extensive enmity among political opponents allowing incumbents to justify abuses of democratic norms to restrain the opposition. The unequal economic resources of different nations resulting in economic inequalities driven by global economic forces may threaten the survival and viability of democracy, diminishing the democratic qualities of the nations. Sometimes populism and populist movements in a country also seem to have challenged basic norms of liberal Democracy, causing volatile situations in the country. The challenge for sustaining multi-ethnic democracies is also seen as a significant problem in various nations as restrictions and unequal representation of ethnic minorities in such nations have diminished their democratic quality. Weak institutional structures and functioning is also one of the significant challenges of contemporary democracies. Similarly, due to the electoral cycles, democracies struggle to focus on long-term problems, usually ending up in short-term policy approaches. Competitions among political parties have made the constant need for money for politicians to get elected in the elections. Due to this, democratic systems are being prone to be captured by wealthy and elite groups. Competitive elections formant may generate conflict undercutting a strong sense of national unity and purpose. Chronic voter's ignorance and irrationality have caused problems in performing ideal democratic practices.

Democracy entails the spirit of freedom, the rule of law, independence, selfreliance and above all, the will to achieve and keep them. In developing countries like Nepal, the challenges of fragile democracy are compounded more by poverty and illiteracy. The unsuccessful decentralization process failed to empower the people at the grassroots level for self-governance, self-reliance, and socio-economic development. Corruption by and inefficiency of the political leaders, officers, and bureaucrats has resulted in a lack of trust of the general public, which badly affects the proper and systematic working of democracy in those countries. Anti-social elements such as 
forcing or bribing people to vote for a particular candidate or party in the elections and rigging cause democratic misconduct. Socio-economic inequalities amongst the people have resulted in boycotting poor people to reach political power or win any elections. And lately, many voters are giving weight to the caste and religion of the political candidates. Representatives elected based on caste or religion might work for the welfare of the people belonging only to their caste or religion, which degrades the democratic quality. Criminal activities, wars, violence, terrorism, and political riots massively challenge the ideal democratic conducts. Therefore, a large number of challenges should be addressed by a nation to ensure success for the perfect democracy in that nation.

\section{The Solution to the Challenges of Democracy}

Challenges help for problem identification and bring out constructive solutions for those problems. Every challenge is an opportunity to progress. Similarly, democratic challenges bring opportunities to develop effective democratic conducts, therefore leading the prosperity of the nation to the path of peace and development. Ideal democratic practice is achieved through the first and foremost provider of fundamental rights to all country people. Democratic institutions and democratic principles should be strengthened. The General Section of people should be empowered through these democratic institutions. Democratic reforms should be carried out by political parties, activists, movement groups, and politically- conscious citizens. Ordinary citizens, too, should participate in political affairs. Wrong political parties should be discouraged through a carefully-devised change in the law.

The existing non-democratic regimes should be brought down. The military should not control the government. Thus a sovereign and functional state should be created. Democratic power should be extended to local governments, facilitating decentralization. Federal principles should be expanded to all the national units of the nation. Political empowerment should be provisioned to women as well as minority groups. The influence of elite groups, wealthy, and influential people in democratic decisions should be checked and balanced. Democratic accountability should be maintained through institutional reforms like electoral reforms, reforms to candidate selection, etc. Similarly, deeper social, economic, and even democratic reforms should be conducted. Innovative ways should be focused on maintaining the sustainability of multi-ethnic democracies. Corruption should be controlled and eliminated through a strict rule of law. The efficiency of political leaders, officers, and bureaucrats, should be improved. Anti-social elements like rigging in elections should be discouraged. Racial disputes, violence and wars should be eliminated through strict government rules and supervision. Global education should be promoted. Therefore, good governance should 
be maintained along with proper addressing of public concern that collectively helps to establish ideal practical democracy in every nation.

\section{Future of Democracy}

In changing world, it is uncertain whether modern Democracy will be kept up with the transforming changes. Information and technological revolution is having profound effects on the economy, society and politics positively as well as negatively. Also, millions of people in the developing world are rising out of poverty, and there has been an increase in a non-ideological and secular approach. Because of this, it's harder to predict the opportunities, threats and effectiveness that a 'Democracy' would have. But the value, viability and future of democracy are more contented now than ever before in modern history.

Corruption, the weak rule of law, inequality, low-level of trust in political institutions, unemployment, and rising nationalism threatens democracy. So, democracy needs to be strengthened more. The 'Third Wave' of democracy has swept through Southern Europe, Latin America, Central and Eastern Europe, Africa, and several South-East Asian Countries, transitions to democracy have become a global phenomenon (Freedom House, 2019). The preferred form of government in most parts of the world is a Liberal Democracy. The quality of democracy has a direct bearing on a country's ability to meet current and future challenges. So, good governance, civil discourse on public policymaking, absence of corruption, provision of employment to all, the proper rule of law, transparent and accountable authority and other more elements are required for the sustainability of democracy.

\section{Conclusion}

Democracy is the form of government in which the ruling power is vested in ordinary people, and political power is exercised by them. Genuine democracy includes essential elements like the competition of parties and individuals in an election with the elections being fair and free, political equality, universal adult suffrage, majority decision, and governmental transparency and accountability. However, the expansion of democracy has not been smooth, and straight. Democratic erosion is occurring in different settings and contexts. New democracies have often become weak and fragile, whereas old democracies struggle to guarantee equitable and sustainable economic and social development. Thus, Democracy needs to show and meet the expectation regarding the sustainable development of the nation through good governance, the 
proper rule of law, freedom of assembly and speech, inclusiveness, equality, membership consent, voting, minority rights, and other better democratic practices. Without the existence of these norms and values democracy cannot sustain.

\section{References}

British Library (2015). Magna Carta. London.

Calhoun, John (2018). Issues of Democracy. Retrieved from

https://www3.nd.edu/ amcadams/CAPP485/StudentWebPages/democracy/demo cracy/definition.html

Chambers, John W. (2000). The Oxford Companion to American Military History.

London: Oxford University.

Churchill, Winston (1947). The Worst Form of Government. Cambridge: International Churchill Society.

Cincotta, Howard (2017). Democracy in Brief. USA: Division of US Studies, Woodrow Wilson International Center for Scholars.

Civatitis (2018). Icelandic Parliament. Civitatis: UK.

Co-Intelligence Institute (2018). THREE DIMENSIONS

OF WISE DEMOCRACY. USA: Eugene.

Dahl, R.A. (2012). Democracy. New Haven: Yale University Press.

Dahl, R.A. (1998). On Democracy. New Haven: Yale University Press.

Roser, Max (2020). Democracy. England: Our World in Data.

Freedom House (2019). Democracy in Treat. Retrieved from

https://freedomhouse.org/report/freedom-world/2019/democracy-retreat

House of Commons (1628). The Petition of Right. London.

ICJ (2018). International Court of Justice. Geneva.

International IDEA (2019). The Global Status of Democracy. Stromsborg.

Joshi, B. L., and Leo, E.G. (2004). Democratic Innovations in Nepal. Kathmandu: Mandala Publication.

KAS (2011). Concepts and Principles of Democratic Governance and Accountability. Uganda: Konrad-Adenauer-Stiftung.

Library of Congress (1919). Stars and Stripes: The American Soldiers' Newspaper of World War I, 1918 to 1919. USA.

Lincoln, Abraham (1863). The Gettysburg Address. Galesburg: Abraham Lincoln Online.

Manutius, Aldus (1502). THUCYDIDES (c.460/455 - c.399 B.C.). [De belloPeloponnesiaco, in Greek]. Venice: Aldus Manutius. 
MOAD (2018). Defining Democracy. Parkes: Museum of Australian Democracy at Old Parliament House.

Oliver, Diana Buitron (1993). THE GREEK MIRACLE. Washington: National Gallery of Art.

Prater, D. (2019). The Global State of Democracy. Stockholm: Bull Graphics.

Riker, William H. (2017). Democracy. USA: Scholastic Teachables.

Rosenberg, Chuck (2011). Cosmopolitan Democracy as Global Governance. Retrieved from http://www.oneworlduv.com/wpcontent/uploads/2011/06/note_cosmopolitan_democracy-global_governance.pdf

Schattschneider, E. E. (1960). The Semi-Sovereign People: A Realist's View of Democracy in America. England: Oxford University.

Salsburg, Jay (2005). Principals of Democracy. USA: Shree America.

SJSU (2020). The Principles of Democracy. California: San Jose State University.

UK Parliament (1832). The Reform Act of 1832. England.

UN (2015). Envision 2030: 17 goals to transform the world for persons with disabilities. New York: Programme on Disability/SCRPD.

Yale Law School (2008). English Bill of Rights 1689. New Haven. 